University of Nebraska - Lincoln

DigitalCommons@University of Nebraska - Lincoln

Publications from USDA-ARS / UNL Faculty

U.S. Department of Agriculture: Agricultural

Research Service, Lincoln, Nebraska

2007

\title{
Long-Term Application of Biosolids on Apricot Production
}

Gary S. Bañuelos

United States Department of Agriculture-Agriculture Research Service, gbanuelos@fresno.ars.usda.gov

Sajeemas Pasakdee

United States Department of Agriculture-Agriculture Research Service

Sharon E. Benes

California State University - Fresno

Craig R. Ledbetter

United States Department of Agriculture-Agriculture Research Service

Follow this and additional works at: https://digitalcommons.unl.edu/usdaarsfacpub

Part of the Agricultural Science Commons

Ban uelos, Gary S.; Pasakdee, Sajeemas; Benes, Sharon E.; and Ledbetter, Craig R., "Long-Term Application of Biosolids on Apricot Production" (2007). Publications from USDA-ARS / UNL Faculty. 517. https://digitalcommons.unl.edu/usdaarsfacpub/517

This Article is brought to you for free and open access by the U.S. Department of Agriculture: Agricultural Research Service, Lincoln, Nebraska at DigitalCommons@University of Nebraska - Lincoln. It has been accepted for inclusion in Publications from USDA-ARS / UNL Faculty by an authorized administrator of DigitalCommons@University of Nebraska - Lincoln. 


\title{
Long-Term Application of Biosolids on Apricot Production
}

\author{
Gary S. Bañuelos and Sajeemas Pasakdee \\ United States Department of Agriculture-Agriculture Research Service, \\ Water Management Research Unit, Parlier, California, USA \\ Sharon E. Benes \\ California State University Fresno, Plant Science Department, Fresno, \\ California, USA \\ Craig A. Ledbetter \\ United States Department of Agriculture-Agriculture Research Service, \\ Crop Diseases, Pests and Genetics Unit, Parlier, California, USA
}

\begin{abstract}
The use and disposal of biosolids, or wastewater treatment sludge, as a fertilizer and soil amendment is becoming increasingly widespread. We evaluated the multiyear use of biosolids in apricot (Prunus armeniaca L.) production, grown on productive agricultural soils. Class A biosolids were initially applied annually at rates of 0 , $1.9,5.8$, and $11.7 \mathrm{Mg} \cdot \mathrm{ha}^{-1}$ (dry basis) to a 2-year-old apricot orchard on the USDAARS research site on the eastern side of the San Joaquin Valley, CA. These application rates provided estimated rates of 0 (control), 57, 170, and $340 \mathrm{~kg}$ total $\mathrm{N} \cdot \mathrm{ha}^{-1} \mathrm{yr}^{-1}$, respectively. Compared to the control treatment, the applications of biosolids significantly increased soil salinity (electrical conductivity from 1:1 soil-water extract) and total concentrations of nutrients [e.g., calcium $(\mathrm{Ca})$, magnesium $(\mathrm{Mg})$, sulfur $(\mathrm{S})$, phosphorus $(\mathrm{P})$, zinc $(\mathrm{Zn})$, and copper $(\mathrm{Cu})]$ after 7 years but did not increase the concentrations of selected metals [cadmium $(\mathrm{Cd})$, chromium $(\mathrm{Cr})$, cobalt $(\mathrm{Co})$, nickel $(\mathrm{Ni})$, and lead $(\mathrm{Pb})]$ between 0 - and $60-\mathrm{cm}$ soil depths. Mean concentrations of total nitrogen $(\mathrm{N})$ and carbon $(\mathrm{C})$ in soils (0- to $15-\mathrm{cm}$ depth) ranged from a low of $1.3 \mathrm{~g} \mathrm{~kg}^{-1}$ to a high of $5.2 \mathrm{~g} \cdot \mathrm{kg}^{-1}$ and from $14.1 \mathrm{~g} \cdot \mathrm{kg}^{-1}$ to $45.7 \mathrm{~g} \cdot \mathrm{kg}^{-1}$ for the control and high biosolids treated soils, respectively.
\end{abstract}

Received 26 May 2006, Accepted 21 July 2006

Address correspondence to Gary S. Bañuelos, United States Department of Agriculture-Agriculture Research Service, Water Management Research Unit, 9611 S. Riverbend Ave., Parlier, CA 93648, USA. E-mail: gbanuelos@fresno.ars.usda.gov 
Biosolids applications did not lead to fruit yield reductions, although fruit maturation was generally delayed and more fruits appeared at picking times at the high rate of application. Yellow fruits collected from all biosolids applications were significantly firmer than were fruit collected from control trees, and they had higher concentrations of $\mathrm{Ca}$, potassium $(\mathrm{K}), \mathrm{S}$, iron $(\mathrm{Fe})$, and $\mathrm{Zn}$ in the fruit. Among the fruit quality parameters tested, the juice $\mathrm{pH}$, total acidity, and fruit skin color were not significantly affected by biosolids applications. Malic acid concentrations decreased most of the time, while citric acid concentrations increased with increasing rates of biosolids applications. Overall, our results suggest that nonindustrial biosolids applied at an annual rate at or less than $11.7 \mathrm{Mg} \mathrm{N} \cdot \mathrm{ha}^{-1}\left(340 \mathrm{~kg} \mathrm{~N} \cdot \mathrm{ha}^{-1}\right)$ can be safely used for apricot production on sandy loam soils.

Keywords: Apricot, biosolids, fruit quality, nutrients, sewage sludge, trace elements

\section{INTRODUCTION}

Nutrient input from utilizing sewage sludge or "biosolids" is under serious consideration in agriculture because more than 5 million $\mathrm{Mg}$ of dry municipal sewage sludge are generated in the United States each year (National Research Council 1996). Biosolids, also called treated municipal sewage sludge, are used as supplemental fertilizers and soil amendments on cropland. The greatest commercial use for this material is as agricultural compost because biosolids can contain most essential macro- and micronutrients for plants (Parr and Hormick 1992; USEPA 1993). Biosolids quality will, however, vary widely in its chemical, biological, and physical properties, depending on such factors as the source and composition of the sewage, the treatment system, the extent to which the material is digested and stabilized, and how the material is handled between processing and application to the soil (Oberle and Keeney 1994). Hence, concerns regarding biosolids utilization in agriculture are primarily related to the content of contaminants referred to as nonessential elements (e.g., $\mathrm{Cd}, \mathrm{Cr}, \mathrm{Co}, \mathrm{Ni}$ ) residing in the soil after application and their potential accumulation by the plant (Chang and Page 2000).

The effects of biosolids on growth and productivity of horticultural crops have been studied extensively (Bradford and Peterson 2000; Brown et al. 1998; Bryan and Lance 1991; Chaney et al. 1978; Chang, Hyun, and Page 1997; Davis and Carlton-Smith 1984; Faust and Oberst 1996; Maynard 1995; Ozores-Hampton et al. 1994; Perez Espinoza et al. 1999), but little research has evaluated its use on tree fruit crops. The Central Valley of California is presently the main production area of stone fruits, supplying approximately 90\% of the U.S. crop (Agricultural Crop and Livestock Report 2002). Apricot (Prunus armeniaca L.) is a major stone fruit grown in this region and is consumed fresh, dried, and in canned products. From the standpoint of public acceptance, applying biosolids to tree fruit production may be a disposal option to seriously consider because the biosolids and its constituents will not come 
into direct contact with fruit produced on the tree. Furthermore, being a perennial rather than an annual crop system, the problem of potentially rotating in a vegetable crop for which biosolids application is not permissible is avoided.

Most conventional growers would prefer synthetic fertilizer applications because the nutrients, especially nitrogen $(\mathrm{N})$, are readily available for plant uptake (Doerge and Klaas 1996) and are not directly influenced by such factors as mineralization rate, metal interactions, adsorption, chelation, precipitation, and $\mathrm{pH}$ to the same degree as biosolids (Chaney 1994). However, because of the low fertilizer requirements for fruit crops grown in normal agricultural soils, the actual phyto-availability of essential macroand micronutrients from applied biosolids may not be so crucial in maintaining normal fruit production. The evaluation of the impact of multiyear biosolid applications on apricot production would be extremely helpful before making recommendations for long-term biosolid application or disposal in tree fruit production. The objectives were to examine for positive or negative consequences on apricot fruit production from multiyear applications of biosolids to typical, sandy loam agricultural soils.

\section{MATERIALS AND METHODS}

\section{Experimental Design, Biosolid Application, and Irrigation}

This multiyear field study was first established in February 1994 at the USDAARS research facilities in Fresno, CA, on land that was previously in almond production. We are presently reporting data from the last 2 years of the study (1999-2000) and fruit yield data from 1998 to 2000. One hundred and ninetytwo apricot trees (var. 'Patterson' on 'Marianna' rootstock) were planted in 1992 on a 0.3 hectare experimental block containing 16 rows of trees with 12 trees per row. Tree spacing was $3.0 \mathrm{~m}$ between trees and $5 \mathrm{~m}$ between rows. The soil, a Hanford sandy loam (coarse-loamy, mixed, superactive, nonacid, thermic, Typic Xerorthents) was amended annually with good quality, class A, dry biosolids provided by Pima Gro Systems, Inc., Redlands, CA. The elemental composition of these biosolids which were stored and covered in a lined plastic pit in the soil, is shown in Table 1. The mean biosolids application rates of $0,1.9,5.8$, and $11.7 \mathrm{Mg} \cdot \mathrm{ha}^{-1}$ (dry basis) were based on providing the following amounts of total $\mathrm{N}$ (in $\mathrm{kg} \mathrm{N} \cdot \mathrm{ha}^{-1}$ ) determined on an annual basis: control (0), low (57), medium (170), and high (340). No additional fertilizer was applied to any treatment, including the control throughout the study. Trees received annual, commercial thinning and pruning practices.

Treatments were arranged in a randomized complete block design with four replications. A replication consisted of an entire row of trees receiving a given application rate of biosolids. The biosolids were hand applied annually in October to the soil surface at the base of each dormant apricot tree in a $2.6-\mathrm{m}^{2}$ plot and incorporated to a depth of $15 \mathrm{~cm}$ with a rototiller 
Table 1. Mean total element concentrations in Class A biosolids applied to apricot orchard soils during of the study ${ }^{a}$

\begin{tabular}{lc}
\hline Element & Total $\left(\mathrm{mg} \mathrm{kg}^{-1}\right)$ \\
\hline $\mathrm{N}$ & $28,900(1030)^{b}$ \\
$\mathrm{Ca}$ & $62,800(5300)$ \\
$\mathrm{Mg}$ & $5,370(140)$ \\
$\mathrm{K}$ & $2,540(110)$ \\
$\mathrm{S}$ & $21,170(1496)$ \\
$\mathrm{P}$ & $24,830(1085)$ \\
$\mathrm{Fe}$ & $48,090(1520)$ \\
$\mathrm{Al}$ & $16,370(410)$ \\
$\mathrm{B}$ & $33(3)$ \\
$\mathrm{Na}$ & $4,663(117)$ \\
$\mathrm{Mn}$ & $243(5)$ \\
$\mathrm{Zn}$ & $818(20)$ \\
$\mathrm{Cu}$ & $588(19)$ \\
$\mathrm{Cd}$ & $3(0.3)$ \\
$\mathrm{Co}$ & $6(1)$ \\
$\mathrm{Cr}$ & $43(4)$ \\
$\mathrm{Ni}$ & $55(4)$ \\
\hline \multicolumn{2}{c}{${ }^{a}$ Other parameters include $\mathrm{pH}(7.3), \mathrm{EC}(32$} \\
$\left.\mathrm{dS} \mathrm{m}^{-1}\right)$, and total solids content $\approx 75 \%$. \\
${ }^{b}$ Mean value (n=6) with standard error in \\
parenthesis. \\
${ }^{c}$ Extractable $\mathrm{NO}_{3}-\mathrm{N}$ was $472(58) \mathrm{mg} \mathrm{L}^{-1}$. \\
\multicolumn{2}{c}{}
\end{tabular}

within 7 days of application. Mineralization rates of biosolids were not estimated. Each tree had two "C"'-pattern Fan-Jet microsprayers (Bowsmith Inc., Exeter, CA) that delivered water at $1.4 \mathrm{~L} \mathrm{~min}^{-1}$ in a radius of $1.8 \mathrm{~m}$ at a pressure of $103 \mathrm{KPa}$. Water was applied based on estimated crop evapotranspiration losses using reported crop coefficient $(\mathrm{Kc})$ values for apricots (Allen et al. 1998) and on weather data downloaded from the California Irrigation Management Information System (CIMIS) in Fresno, CA.

\section{Elemental Analyses in Soil and Fruit}

Soil and Plant Analysis

Soil samples were collected from depths of $0-15,15-30,30-45$, and 45$60 \mathrm{~cm}$, in an approximately $50-\mathrm{cm}$ radius from the trunk. For each replication, two trees (one each from the western and eastern ends) were randomly selected from each row. A composite sample from four soil cores was made 
from each tree at the respective depth. Samples were ovendried at $65^{\circ} \mathrm{C}$ for 7 days and finely ground using a "Quaker City Mill" soil grinder (Philadelphia, $\mathrm{PA})$. The $\mathrm{pH}$ and soil salinity $\left(\mathrm{EC}=\right.$ electrical conductivity in $\mathrm{dS} \cdot \mathrm{m}^{-1}$ ) were determined from a 1:1 soil-water extract, and concentrations of designated total elements were determined in soils and in plants after acid digestion with nitric acid $\left(\mathrm{HNO}_{3}\right)$, hydrogen peroxide $\left(\mathrm{H}_{2} \mathrm{O}_{2}\right)$, and hydrochloric acid (HCl) (Soltanpour et al. 1996). Data are only presented from the postharvest soil sampling at the end of the 2000 growing season. Total concentrations of nutrients and selected elements [calcium $(\mathrm{Ca})$, magnesium $(\mathrm{Mg})$, potassium $(\mathrm{K})$, phosphorus $(\mathrm{P})$, sulfur $(\mathrm{S})$, boron $(\mathrm{B})$, manganese $(\mathrm{Mn})$, zinc $(\mathrm{Zn})$, copper $(\mathrm{Cu})$, cadmium $(\mathrm{Cd})$, chromium $(\mathrm{Cr})$, cobalt $(\mathrm{Co})$, and nickel (Ni)] were analyzed by inductively coupled plasma emission spectrometry (ICP) [(Perkin Elmer, Plasma 2000 Emission Spectrometer, Norwalk, CT)]. Apricot leaves and the 0 - to $15-\mathrm{cm}$-depth soil samples were measured for total $\mathrm{N}$ and carbon (C) by a LECO combustion analyzer CN2000 (St. Joseph, MI).

\section{Fruit Quality}

Fruit yields were eventually large enough to commercially harvest from 1998 to 2000 using a farm labor crew. Fruit picked in the 1999 and 2000 growing seasons was evaluated for quality parameters. Three to six trees per row were selected, and a southeastern scaffold of the selected trees was marked. The selected scaffold contained at least 100 fruits. Each of the selected scaffolds was picked at a total of three times in 3-day intervals with all fruits being picked, regardless of maturity. Immediately after harvest, the fruits were separated according to overall fruit color (green-yellow, yellow, or orange). The total number of fruits in each color category was recorded separately for each row (replication), and the total fruit yield for all colors was recorded for each treatment.

For each replication, ten fruits were selected from each color category to be bagged for further analyses. Pits were removed from the fruit, and the flesh was cut into small pieces. The fruit tissues were ovendried at $65^{\circ} \mathrm{C}$ for 7 days and ground, and selected element levels were analyzed by ICP after acid digestion (described earlier). Some fruit pits were evaluated for elemental accumulation as a potential storage site for nonessential elements (data not reported because of low concentrations for all treatments). The following fruit quality parameters were also evaluated both in the harvested fruit (described earlier) and in the apricot juice that was extracted with a Panasonic juice extractor (Tokyo, Japan):

1. Fruit flesh firmness. Fruits were peeled very thinly on both cheeks and tested for the flesh firmness by using a Dballauf handheld penetrometer (Washington, DC) equipped with 8-mm tip. 
2. Brix. Apricot juice was analyzed directly for soluble solid content (brix) using a Leica 10430 handheld refrectometer (Buffalo, NY).

3. Total $\mathrm{pH}$ and acidity. Apricot juice was tested for $\mathrm{pH}$ and total acidity using a titration method reported by Ledbetter et al. (1996) with a Mettler DL21 titrator (Hightstown, NJ).

4. Organic acid content. Apricot juice was analyzed for ascorbic, citric, and malic acid content by using a Dionex ion chromatography (Sunnyvale, CA), as described by Leuzzi and Licandro (1997).

Data Analysis

Data are presented as mean and standard deviation. Analysis of variance (ANOVA) was performed using the Number Cruncher Statistical System (NCSS) 2000 (Kaysville, UT). Fisher's LSD multiple comparison test was used for mean separation at $\mathrm{P} \leq 0.05$.

\section{RESULTS}

\section{Elemental Composition in Soil}

Table 2 shows the essential nutrients in soils at depths of $0-15,15-30$, $30-45$, and $45-60 \mathrm{~cm}$ for the postharvest 2000 growing season. Total concentrations of $\mathrm{Ca}, \mathrm{S}, \mathrm{P}, \mathrm{Mn}, \mathrm{Zn}$, and $\mathrm{Cu}$ increased with all rates of biosolid applications at the 0 - to $15-\mathrm{cm}$ depth (Table 2), whereas total concentrations of $\mathrm{Cd}, \mathrm{Co}, \mathrm{Cr}, \mathrm{Ni}$, and $\mathrm{Pb}$ were not significantly greater than the control for any treatment or for any depth (data not shown). Total $\mathrm{N}$ at the $0-$ to $15-\mathrm{cm}$ depth increased from an initial mean concentration of $0.4 \mathrm{~g} \mathrm{~kg}^{-1}$ prior to initial biosolid application in 1994, to the following concentrations for all treatments in 2000: control (1.3), low (1.9), medium (3.0), and high $\left(5.2 \mathrm{~g} \mathrm{~kg}^{-1}\right)$, whereas the initial concentration of total $\mathrm{C}$ of $4.8 \mathrm{~g} \mathrm{~kg}^{-1}$ increased to the following concentrations in 2000: control (14.1), low (25.0), medium (38.6), and high $\left(45.7 \mathrm{~g} \mathrm{~kg}^{-1}\right)$. Generally, soil EC increased in proportion to the rate of biosolid application, although there were no significant differences in salinity among the soil depths for each respective rate of biosolid application (Table 2). Soil pH ranged from 7.2 to 7.4 for all biosolids application rates for all measured soil depths (data not shown).

\section{Fruit Yield and Quality}

Biosolid application did not appear to influence total fruit yield in any of the growing seasons from 1998 to 2000 (Table 3). Pickers did not separate picked fruits by replicates for the respective treatments, hence statistics were not 
Table 2. Concentration of acid-soluble (total) macronutrients and micronutrients in soils for various depths and biosolids application rates at the end of the 2000 growing the season ${ }^{a}$

\begin{tabular}{|c|c|c|c|c|c|c|c|c|c|c|}
\hline $\begin{array}{l}\text { Treatment } \\
\left(\mathrm{kg} \mathrm{N} \mathrm{ha}^{-1}\right)\end{array}$ & $\begin{array}{l}\text { Depth } \\
(\mathrm{cm})\end{array}$ & $\begin{array}{c}\mathrm{EC} \\
\left(\mathrm{ds} \mathrm{m}^{-1}\right)\end{array}$ & $\begin{array}{c}\mathrm{Ca} \\
\left(\mathrm{mg} \mathrm{kg}^{-1}\right)\end{array}$ & $\begin{array}{c}\mathrm{Mg} \\
\left(\mathrm{mg} \mathrm{kg}^{-1}\right)\end{array}$ & $\begin{array}{c}\mathrm{K} \\
\left(\mathrm{mg} \mathrm{kg}^{-1}\right)\end{array}$ & $\begin{array}{c}\mathrm{S} \\
\left(\mathrm{mg} \mathrm{kg}^{-1}\right)\end{array}$ & $\begin{array}{c}\mathrm{P} \\
\left(\mathrm{mg} \mathrm{kg}^{-1}\right)\end{array}$ & $\begin{array}{c}\mathrm{Mn} \\
\left(\mathrm{mg} \mathrm{kg}^{-1}\right)\end{array}$ & $\begin{array}{c}\mathrm{Zn} \\
\left(\mathrm{mg} \mathrm{kg}^{-1}\right)\end{array}$ & $\begin{array}{c}\mathrm{Cu} \\
\left(\mathrm{mg} \mathrm{kg}^{-1}\right)\end{array}$ \\
\hline \multirow[t]{5}{*}{0} & $0-15$ & $\begin{array}{r}0.2^{b} \mathrm{~d}^{c} \\
(0.0)\end{array}$ & $\begin{array}{c}2539 \mathrm{~h} \\
(158)\end{array}$ & $\begin{array}{c}2675 \mathrm{e} \\
(59)\end{array}$ & $\begin{array}{c}2019 b \\
(35)\end{array}$ & $\begin{array}{c}155 \mathrm{ef} \\
(17)\end{array}$ & $\begin{array}{l}267 f \\
(23)\end{array}$ & $\begin{array}{c}159 \mathrm{c} \\
(6)\end{array}$ & $\begin{array}{l}53 \mathrm{~cd} \\
(5)\end{array}$ & $\begin{array}{l}12 \mathrm{e} \\
(0)\end{array}$ \\
\hline & $15-30$ & $\begin{array}{l}0.3 \mathrm{~d} \\
(0.1)\end{array}$ & $\begin{array}{l}2072 \mathrm{i} \\
(129)\end{array}$ & $\begin{array}{c}2839 \mathrm{~cd} \\
(188)\end{array}$ & $\begin{array}{c}2400 \mathrm{ab} \\
(112)\end{array}$ & $\begin{array}{l}91 \mathrm{~g} \\
(7)\end{array}$ & $\begin{array}{l}257 f \\
(20)\end{array}$ & $\begin{array}{c}199 \mathrm{bc} \\
(8)\end{array}$ & $\begin{array}{l}43 d \\
(6)\end{array}$ & $\begin{array}{l}15 \mathrm{de} \\
(0)\end{array}$ \\
\hline & $30-45$ & $0.3 \mathrm{~d}$ & $2065 \mathrm{i}$ & $3114 \mathrm{~cd}$ & 2391ab & $58 \mathrm{~h}$ & $159 \mathrm{~g}$ & $255 b$ & $45 \mathrm{~d}$ & $13 \mathrm{de}$ \\
\hline & & (0.0) & (294) & $\begin{array}{c}\text { (279) } \\
\text { (2) }\end{array}$ & (122) & (9) & (29) & (19) & (4) & $\begin{array}{l}(0) \\
\end{array}$ \\
\hline & $45-60$ & $\begin{array}{l}0.4 \mathrm{~d} \\
(0.1)\end{array}$ & $\begin{array}{l}1893 i \\
(170)\end{array}$ & $\begin{array}{c}3120 \mathrm{~cd} \\
(365)\end{array}$ & $\begin{array}{l}2442 \mathrm{ab} \\
(213)\end{array}$ & $\begin{array}{l}52 \mathrm{~h} \\
(8)\end{array}$ & $\begin{array}{l}230 f \\
(16)\end{array}$ & $\begin{array}{r}282 \mathrm{a} \\
(13)\end{array}$ & $\begin{array}{l}48 \mathrm{~d} \\
(3)\end{array}$ & $\begin{array}{l}14 \mathrm{de} \\
(0)\end{array}$ \\
\hline \multirow[t]{6}{*}{57} & $0-15$ & $\begin{array}{l}0.6 \mathrm{~cd} \\
(0.0)\end{array}$ & $\begin{array}{l}3560 f \\
(338)\end{array}$ & $\begin{array}{l}2809 d \\
(178)\end{array}$ & $\begin{array}{c}2122 b \\
(119)\end{array}$ & $\begin{array}{l}314 d \\
(13)\end{array}$ & $\begin{array}{c}688 \mathrm{de} \\
(58)\end{array}$ & $\begin{array}{c}193 b c \\
(15)\end{array}$ & $\begin{array}{l}109 \mathrm{~b} \\
(6)\end{array}$ & $\begin{array}{l}27 c \\
(2)\end{array}$ \\
\hline & $15-30$ & $\begin{array}{l}0.7 \mathrm{c} \\
(0.0)\end{array}$ & $\begin{array}{l}3436 f \\
(330)\end{array}$ & $\begin{array}{l}3246 c \\
(1057)\end{array}$ & $\begin{array}{c}2204 b \\
(111)\end{array}$ & $\begin{array}{c}164 \mathrm{e} \\
(6)\end{array}$ & $\begin{array}{l}448 \mathrm{e} \\
(16)\end{array}$ & $\begin{array}{l}200 \mathrm{bc} \\
(12)\end{array}$ & $\begin{array}{l}76 c \\
(4)\end{array}$ & $\begin{array}{l}16 \mathrm{de} \\
(0)\end{array}$ \\
\hline & $30-45$ & $0.9 \mathrm{c}$ & $3269 \mathrm{fg}$ & $3488 \mathrm{c}$ & $2238 b$ & $129 \mathrm{f}$ & $404 \mathrm{e}$ & $231 \mathrm{~b}$ & $64 c$ & $13 \mathrm{de}$ \\
\hline & & $(0.1)$ & (274) & (1100) & (72) & (8) & (46) & (7) & (3) & (0) \\
\hline & $45-60$ & $0.9 \mathrm{c}$ & $2982 \mathrm{~g}$ & $4278 b$ & $2648 \mathrm{a}$ & $87 \mathrm{~g}$ & $268 \mathrm{f}$ & $304 a$ & $53 \mathrm{~cd}$ & $15 \mathrm{de}$ \\
\hline & & (0.0) & (388) & (1306) & (236) & (9) & (17) & (14) & (7) & (0) \\
\hline \multirow[t]{6}{*}{170} & $0-15$ & $1.4 \mathrm{~b}$ & $4641 \mathrm{~cd}$ & $3051 \mathrm{~cd}$ & $2067 \mathrm{~b}$ & $480 \mathrm{c}$ & $1271 \mathrm{c}$ & $192 b c$ & $114 b$ & $45 b$ \\
\hline & & (0.1) & $(310)$ & (689) & (72) & (15) & (183) & (16) & (5) & (5) \\
\hline & $15-30$ & $1.5 \mathrm{~b}$ & $3911 \mathrm{e}$ & $3147 \mathrm{~cd}$ & $2201 b$ & $173 \mathrm{e}$ & $1123 \mathrm{c}$ & $177 \mathrm{c}$ & $75 c$ & $28 \mathrm{c}$ \\
\hline & & (0.1) & $(368)$ & (259) & (92) & (13) & (179) & (1) & (3) & (0) \\
\hline & $30-45$ & $1.8 \mathrm{~b}$ & $3093 \mathrm{~g}$ & $4256 a b$ & $2711 \mathrm{a}$ & $131 \mathrm{ef}$ & 791d & $334 a$ & $66 c$ & $17 \mathrm{~d}$ \\
\hline & & (0.0) & (187) & $(212)$ & (274) & (10) & (82) & (16) & (3) & (0) \\
\hline
\end{tabular}


Table 2. Continued

\begin{tabular}{|c|c|c|c|c|c|c|c|c|c|c|}
\hline $\begin{array}{l}\text { Treatment } \\
\left(\mathrm{kg} \mathrm{N} \mathrm{ha}^{-1}\right)\end{array}$ & $\begin{array}{l}\text { Depth } \\
(\mathrm{cm})\end{array}$ & $\begin{array}{c}\mathrm{EC} \\
\left(\mathrm{ds} \mathrm{m}^{-1}\right)\end{array}$ & $\begin{array}{c}\mathrm{Ca} \\
\left(\mathrm{mg} \mathrm{kg}^{-1}\right)\end{array}$ & $\begin{array}{c}\mathrm{Mg} \\
\left(\mathrm{mg} \mathrm{kg}^{-1}\right)\end{array}$ & $\begin{array}{c}\mathrm{K} \\
\left(\mathrm{mg} \mathrm{kg}^{-1}\right)\end{array}$ & $\begin{array}{c}\mathrm{S} \\
\left(\mathrm{mg} \mathrm{kg}^{-1}\right)\end{array}$ & $\begin{array}{c}\mathrm{P} \\
\left(\mathrm{mg} \mathrm{kg}^{-1}\right)\end{array}$ & $\begin{array}{c}\mathrm{Mn} \\
\left(\mathrm{mg} \mathrm{kg}^{-1}\right)\end{array}$ & $\begin{array}{c}\mathrm{Zn} \\
\left(\mathrm{mg} \mathrm{kg}^{-1}\right)\end{array}$ & $\begin{array}{c}\mathrm{Cu} \\
\left(\mathrm{mg} \mathrm{kg}^{-1}\right)\end{array}$ \\
\hline & $45-60$ & $\begin{array}{l}1.9 \mathrm{~b} \\
(0.1)\end{array}$ & $\begin{array}{c}\text { 2874gh } \\
(317)\end{array}$ & $\begin{array}{l}4049 b \\
(343)\end{array}$ & $\begin{array}{c}2620 a \\
(96)\end{array}$ & $\begin{array}{l}149 \mathrm{ef} \\
(7)\end{array}$ & $\begin{array}{l}623 d \\
(123)\end{array}$ & $\begin{array}{l}289 a \\
(15)\end{array}$ & $\begin{array}{l}63 c \\
(4)\end{array}$ & $\begin{array}{l}18 \mathrm{~d} \\
(0)\end{array}$ \\
\hline \multirow[t]{4}{*}{340} & $0-15$ & $\begin{array}{l}3.2 \mathrm{a} \\
(0.2)\end{array}$ & $\begin{array}{l}6201 \mathrm{a} \\
(216)\end{array}$ & $\begin{array}{c}3890 \mathrm{~b} \\
(457)\end{array}$ & $\begin{array}{l}2261 b \\
(215)\end{array}$ & $\begin{array}{l}2515 a \\
(222)\end{array}$ & $\begin{array}{l}3120 \mathrm{a} \\
(569)\end{array}$ & $\begin{array}{c}220 \mathrm{~b} \\
(32)\end{array}$ & $\begin{array}{c}271 \mathrm{a} \\
(18)\end{array}$ & $\begin{array}{l}132 \mathrm{a} \\
(15)\end{array}$ \\
\hline & $15-30$ & $\begin{array}{l}3.4 \mathrm{a} \\
(0.1)\end{array}$ & $\begin{array}{c}4191 d \\
(372)\end{array}$ & $\begin{array}{c}3749 b c \\
(367)\end{array}$ & $\begin{array}{c}2495 \mathrm{ab} \\
(248)\end{array}$ & $\begin{array}{l}892 b c \\
(126)\end{array}$ & $\begin{array}{l}1914 b \\
(142)\end{array}$ & $\begin{array}{c}245 b \\
(15)\end{array}$ & $\begin{array}{l}132 \mathrm{~b} \\
(13)\end{array}$ & $\begin{array}{l}50 \mathrm{~b} \\
(4)\end{array}$ \\
\hline & $30-45$ & $\begin{array}{l}3.5 \mathrm{a} \\
(0.2)\end{array}$ & $\begin{array}{l}5299 \mathrm{~b} \\
(303)\end{array}$ & $\begin{array}{l}4410 \mathrm{a} \\
(190)\end{array}$ & $\begin{array}{l}2695 a \\
(174)\end{array}$ & $\begin{array}{l}689 \mathrm{c} \\
(95)\end{array}$ & $\begin{array}{l}1708 b \\
(163)\end{array}$ & $\begin{array}{c}270 \mathrm{ab} \\
(55)\end{array}$ & $\begin{array}{l}121 \mathrm{~b} \\
(13)\end{array}$ & $\begin{array}{l}26 c \\
(7)\end{array}$ \\
\hline & $45-60$ & $\begin{array}{l}3.5 \mathrm{a} \\
(0.1)\end{array}$ & $\begin{array}{l}4282 d \\
(250)\end{array}$ & $\begin{array}{c}4646 a \\
(193)\end{array}$ & $\begin{array}{l}2798 \mathrm{a} \\
(256)\end{array}$ & $\begin{array}{l}527 \mathrm{c} \\
(81)\end{array}$ & $\begin{array}{l}845 \mathrm{~cd} \\
(111)\end{array}$ & $\begin{array}{l}290 \mathrm{a} \\
(77)\end{array}$ & $\begin{array}{l}87 \mathrm{c} \\
(12)\end{array}$ & $\begin{array}{l}18 \mathrm{~d} \\
(0)\end{array}$ \\
\hline
\end{tabular}

${ }^{a}$ Irrespective of treatment or depth of soil sampling. There were no significant differences in concentrations for the following in ( $\left.\mathrm{mg} \mathrm{kg}^{-1}\right)$ : $\mathrm{Cd}_{(8)}$, Co (8), Cr (51), Ni (48), and Pb (17).

${ }^{b}$ Mean values are followed by standard deviation in parentheses.

${ }^{c}$ Within a column, means followed by the same letter are not significantly different at $\mathrm{P}<0.05$ using Fischer's LSD multiple range test. 
performed on total fruit yield. In 2000, a widespread fungal infection (due to extremely wet conditions) appeared in all treatments, which significantly lowered the fruit yield for all treatments. Delayed fruit maturity (observed as more green/yellow fruit) was generally observed on fruit picked from all biosolids applications (Figure 1). Biosolid application increased the concentrations of $\mathrm{Ca}, \mathrm{K}, \mathrm{S}$, and $\mathrm{Zn}$ in harvested fruit for all biosolid application rates in both 1999 and 2000 (Table 4). Significant amounts of Cd, Cr, Co, $\mathrm{Ni}$, and $\mathrm{Pb}$ were not detected in fruit tissue nor in fruit pits for any of the biosolid treatments (data not shown).

Fruits of the yellow color category were significantly firmer in response to biosolids applications, irrespective of harvest date (Table 5). The biosolid applications did not have any significant lasting effects on soluble solid content (Brix), fruit $\mathrm{pH}$, or total acidity in yellow fruit (data not shown). In contrast, concentrations of citric and ascorbic acid in the fruit increased, whereas malic acid content decreased in 1999 in response to biosolid application (Table 5). Total leaf $\mathrm{N}$ also increased in 1999 and 2000 with increased biosolid application rate (Figure 2).

Table 3. Total apricot fruit yield $\mathrm{Mg} \mathrm{ha}^{-1}$ commercially picked at yellow color stage during the 1998 to 2000 growing seasons for various biosolids application rates

\begin{tabular}{|c|c|c|c|c|c|}
\hline Year & $\begin{array}{l}\text { Treatment } \\
\left(\mathrm{kg} \mathrm{N} \mathrm{ha}^{-1}\right)\end{array}$ & $\begin{array}{l}\text { First harvest } \\
\left(\mathrm{Mg} \mathrm{ha}^{-1}\right)^{a}\end{array}$ & $\begin{array}{c}\text { Second } \\
\text { harvest } \\
\left(\mathrm{Mg} \mathrm{ha}^{-1}\right)\end{array}$ & $\begin{array}{l}\text { Third harvest } \\
\left(\mathrm{Mg} \mathrm{ha}^{-1}\right)\end{array}$ & $\begin{array}{l}\text { Total fruit } \\
\text { yield (Mg } \\
\left.\text { ha }^{-1}\right)^{b}\end{array}$ \\
\hline \multirow{4}{*}{$\begin{array}{l}1998 \text { Growing } \\
\text { season }\end{array}$} & 0 & 16.9 & 2.6 & 0 & 19.5 \\
\hline & 57 & 17.0 & 3.8 & 0 & 20.8 \\
\hline & 170 & 16.7 & 3.3 & 0 & 20.0 \\
\hline & 340 & 16.3 & 6.5 & 0 & 22.8 \\
\hline \multirow{4}{*}{$\begin{array}{l}1999 \text { Growing } \\
\text { season }\end{array}$} & 0 & 13.8 & 10.0 & 2.2 & 26.0 \\
\hline & 57 & 7.2 & 13.2 & 3.2 & 23.6 \\
\hline & 170 & 9.4 & 12.5 & 3.3 & 25.2 \\
\hline & 340 & 5.9 & 12.1 & 4.5 & 22.5 \\
\hline \multirow{4}{*}{$\begin{array}{l}2000 \text { Growing } \\
\text { season }^{c}\end{array}$} & 0 & 7.3 & 4.8 & 0 & 12.2 \\
\hline & 57 & 5.3 & 7.1 & 0 & 12.4 \\
\hline & 170 & 7.6 & 7.0 & 0 & 14.6 \\
\hline & 340 & 3.5 & 6.6 & 0 & 10.1 \\
\hline
\end{tabular}

${ }^{a}$ Each harvest occurred in 5- to 10-day intervals.

${ }^{b}$ Statistical analysis could not be performed on total fruit yield because pickers did not separate fruits by replicates for each treatment.

${ }^{c}$ The weather was excessively wet in 2000 , and a large number of apricot fruits had fungal infection. 


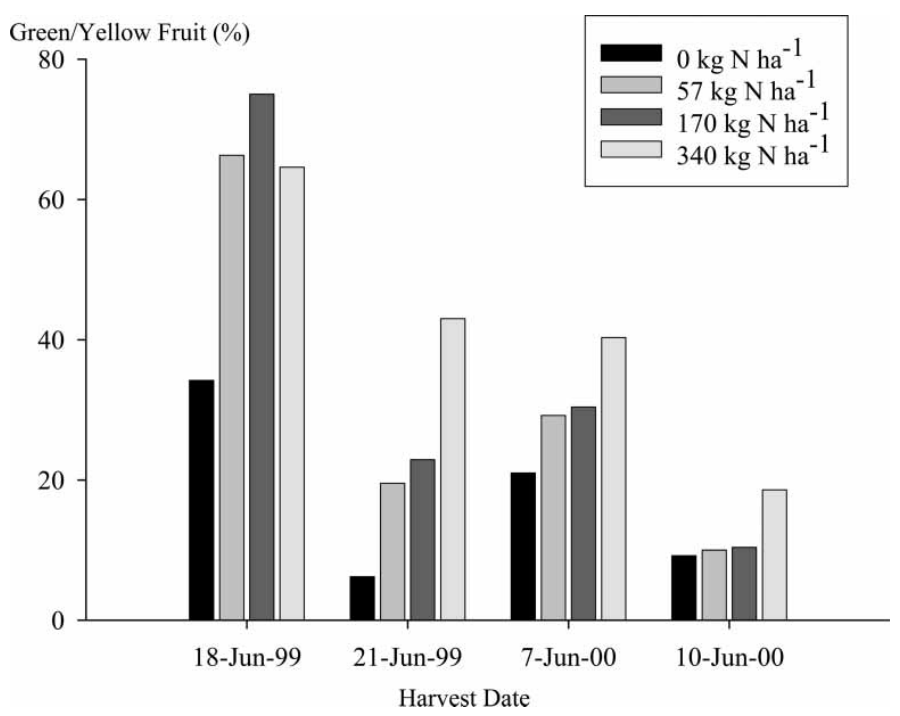

Figure 1. Fruit maturity (percentage of fruits at the green/yellow color stage) for trees receiving various biosolid application rates. Data are for two harvest dates in the 1999 and 2000 growing seasons.

\section{DISCUSSION}

Application of biosolids for 7 years to this apricot orchard eventually increased the soil salinity and total concentrations of most nutrients (except K) in the soil at the 0 - to $15-\mathrm{cm}$ depth. In 2000, the biosolid applications translated into higher concentrations of essential nutrients such as $\mathrm{Ca}, \mathrm{K}, \mathrm{S}, \mathrm{Fe}$, and $\mathrm{Zn}$ in the fruit tissue, whereas the low concentrations of nonessential elements (e.g., $\mathrm{Cd}$, $\mathrm{Cr}, \mathrm{Co}, \mathrm{Ni}$, etc.) were of no concern in the soil and plant tissues in response to biosolid application at any rate (Chang and Page 2000). It is likely that both the application of good-quality biosolids and a soil $\mathrm{pH}$ of 7.3 minimized the solubilization, movement, and uptake of nonessential elements within the soil profile and their subsequent uptake by the apricot trees (Furr et al. 1981; Page, Chang, and Bingham 1979). Pinamonti et al. (1997) also did not measure metal accumulation in apple fruit after the application of apparently high-quality biosolids. Moreover, in this experiment, the total recoverable metal concentrations in our soil were far less than the loading rate values listed by the USEPA (Part 503) after 7 years of biosolids applications (USEPA 1993).

Water treatment plants in California generally produce biosolids with low heavy-metal content because of stringent state regulations and a lack of industrial-based effluent requiring disposal in the state. In addition, because of the USEPA-permitted pretreatment program, which requires industrial facilities to remove pollutants before discharge into municipal sewer systems, heavy-metal pollutants are now typically low in wastewater treatment 
Table 4. Mean elemental concentrations $\left(\mathrm{mg} \mathrm{kg}^{-1}\right)$ in apricot fruit tissue for various biosolids application rates for the 1999 and 2000 growing seasons $^{a}$

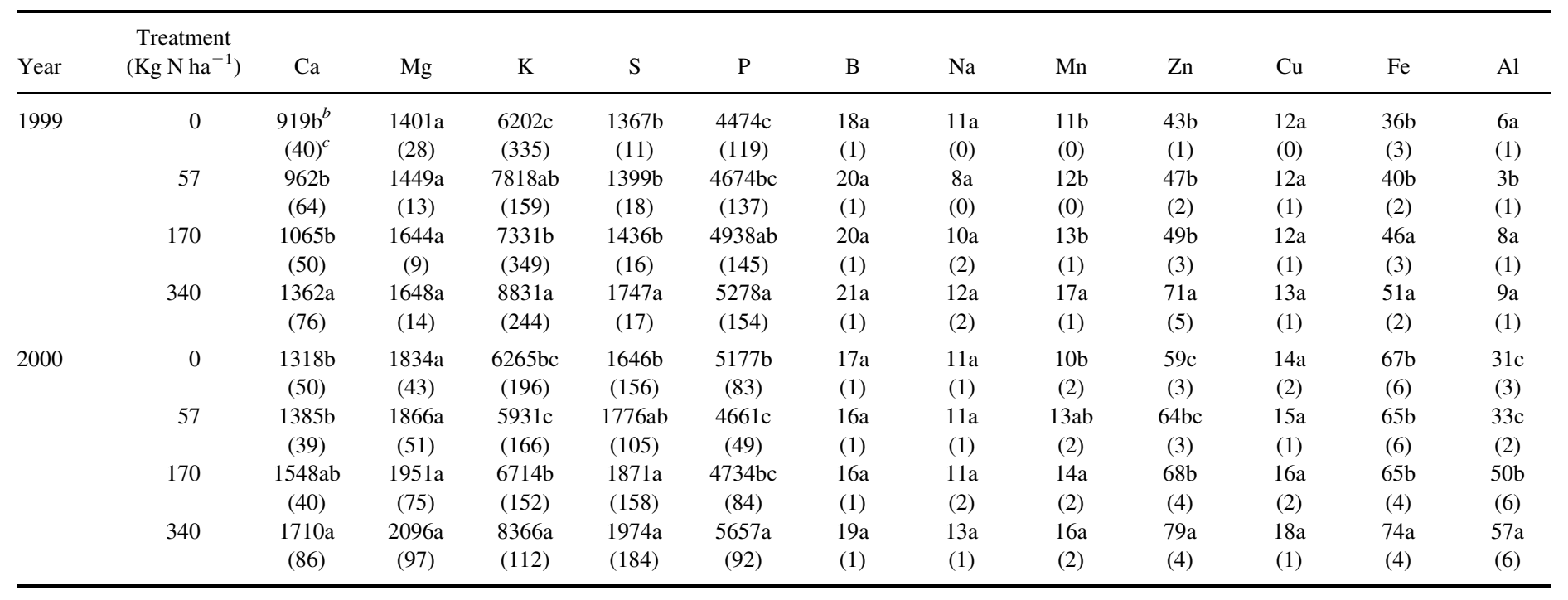

${ }^{a} \mathrm{Cd}, \mathrm{Co}, \mathrm{Cr}, \mathrm{Ni}$, and $\mathrm{Pb}$ concentrations were undetectable.

${ }^{b}$ Means followed by the same letter are not significantly different at $P<0.05$ using Fisher's LSD multiple range test for fruit tissue at each respective growing season.

${ }^{c}$ Mean values are followed by standard deviation in parentheses. 
Table 5. Malic, citric, and ascorbic acid concentrations and firmness in yellow fruit for various biosolid-application rates

\begin{tabular}{|c|c|c|c|c|c|}
\hline Date & $\begin{array}{l}\text { Treatment } \\
\left(\mathrm{kg} \mathrm{N}^{-1}\right) \\
\left.\mathrm{ha}^{-1}\right)\end{array}$ & $\begin{array}{c}\text { Malic } \\
\left(\mathrm{g} \mathrm{kg}^{-1}\right)\end{array}$ & $\begin{array}{c}\text { Citric } \\
\left(\mathrm{g} \mathrm{kg}^{-1}\right)\end{array}$ & $\begin{array}{l}\text { Ascorbic } \\
\left(\mathrm{g} \mathrm{kg}^{-1}\right)\end{array}$ & $\begin{array}{l}\text { Firmness }^{d} \\
\text { (Newtons) }\end{array}$ \\
\hline \multirow[t]{4}{*}{ 15-Jun-99 } & 0 & $\begin{array}{l}13.96 \mathrm{a}^{a} \\
(0.99)^{b}\end{array}$ & $\begin{array}{l}9.91 \mathrm{c} \\
(0.55)\end{array}$ & $\begin{array}{l}0.74 \mathrm{~b} \\
(0.08)\end{array}$ & $55.95 \mathrm{c}(0.89)$ \\
\hline & 57 & $\begin{array}{l}12.49 \mathrm{~b} \\
(0.94)\end{array}$ & $\begin{array}{l}10.03 \mathrm{c} \\
(0.74)\end{array}$ & $\begin{array}{l}0.83 b \\
(0.08)\end{array}$ & $59.14 b(1.19)$ \\
\hline & 170 & $\begin{array}{l}11.55 \mathrm{c} \\
(1.19)\end{array}$ & $\begin{array}{l}12.05 b \\
(0.66)\end{array}$ & $\begin{array}{l}0.86 \mathrm{~b} \\
(0.18)\end{array}$ & $59.90 b(1.62)$ \\
\hline & 340 & $\begin{array}{l}10.39 \mathrm{~d} \\
(0.65)\end{array}$ & $\begin{array}{l}13.62 \mathrm{a} \\
(0.88)\end{array}$ & $\begin{array}{l}1.29 \mathrm{a} \\
(0.24)\end{array}$ & $61.11 \mathrm{a}(1.31)$ \\
\hline \multirow[t]{4}{*}{ 18-Jun-99 } & 0 & $\begin{array}{l}12.56 \mathrm{a} \\
(0.61)\end{array}$ & $\begin{array}{l}8.82 \mathrm{c} \\
(0.27)\end{array}$ & $\begin{array}{l}1.05 \mathrm{~b} \\
(0.37)\end{array}$ & $49.86 \mathrm{c}(1.14)$ \\
\hline & 57 & $\begin{array}{l}11.75 b \\
(0.48)\end{array}$ & $\begin{array}{l}10.41 \mathrm{~b} \\
(0.48)\end{array}$ & $\begin{array}{l}1.09 \mathrm{~b} \\
(0.29)\end{array}$ & $52.71 b(1.34)$ \\
\hline & 170 & $\begin{array}{l}10.84 \mathrm{c} \\
(0.25)\end{array}$ & $\begin{array}{l}\text { 10.82ab } \\
(0.78)\end{array}$ & $\begin{array}{l}1.41 \mathrm{ab} \\
(0.27)\end{array}$ & $53.22 b(0.99)$ \\
\hline & 340 & $\begin{array}{l}9.57 \mathrm{~d} \\
(0.89)\end{array}$ & $\begin{array}{l}11.47 \mathrm{a} \\
(0.74)\end{array}$ & $\begin{array}{l}1.53 \mathrm{a} \\
(0.22)\end{array}$ & $55.66 \mathrm{a}(1.06)$ \\
\hline \multirow[t]{4}{*}{ 21-Jun-99 } & 0 & $\begin{array}{l}11.67 \mathrm{a} \\
(0.81)\end{array}$ & $\begin{array}{l}6.59 \mathrm{~b} \\
(0.49)\end{array}$ & $\begin{array}{l}0.88 \mathrm{~ns}^{c} \\
(0.16)\end{array}$ & $46.08 \mathrm{~b}(1.26)$ \\
\hline & 57 & $\begin{array}{l}11.47 \mathrm{a} \\
(0.61)\end{array}$ & $\begin{array}{l}6.50 \mathrm{~b} \\
(0.52)\end{array}$ & $\begin{array}{l}0.93 \mathrm{~ns} \\
(0.44)\end{array}$ & $46.65 b(1.56)$ \\
\hline & 170 & $\begin{array}{l}9.42 b \\
(0.95)\end{array}$ & $\begin{array}{l}8.19 \mathrm{a} \\
(0.43)\end{array}$ & $\begin{array}{l}1.06 \mathrm{~ns} \\
(0.14)\end{array}$ & $52.30 \mathrm{a}(1.96)$ \\
\hline & 340 & $\begin{array}{l}7.98 \mathrm{c} \\
(0.70)\end{array}$ & $\begin{array}{l}8.22 \mathrm{a} \\
(0.55)\end{array}$ & $\begin{array}{l}1.08 \mathrm{~ns} \\
(0.21)\end{array}$ & $52.75 \mathrm{a}(1.25)$ \\
\hline \multirow[t]{4}{*}{ 7-Jun-00 } & 0 & $\begin{array}{l}9.82 \mathrm{~ns} \\
(0.92)\end{array}$ & $\begin{array}{l}5.97 \mathrm{~b} \\
(0.14)\end{array}$ & $\begin{array}{l}0.76 \mathrm{~b} \\
(0.08)\end{array}$ & 47.98c (1.18) \\
\hline & 57 & $\begin{array}{l}9.78 \mathrm{~ns} \\
(0.83)\end{array}$ & $\begin{array}{l}6.68 \mathrm{a} \\
(1.05)\end{array}$ & $\begin{array}{l}0.85 \mathrm{a} \\
(0.12)\end{array}$ & $50.23 b(0.36)$ \\
\hline & 170 & $\begin{array}{l}9.37 \mathrm{~ns} \\
(0.49)\end{array}$ & $\begin{array}{l}6.70 \mathrm{a} \\
(0.35)\end{array}$ & $\begin{array}{l}0.87 \mathrm{a} \\
(0.11)\end{array}$ & $51.51 \mathrm{ab}(0.49)$ \\
\hline & 340 & $\begin{array}{l}8.95 \mathrm{~ns} \\
(0.76)\end{array}$ & $\begin{array}{l}6.81 \mathrm{a} \\
(0.40)\end{array}$ & $\begin{array}{l}0.88 \mathrm{a} \\
(0.03)\end{array}$ & $51.75 \mathrm{a}(0.96)$ \\
\hline \multirow[t]{3}{*}{ 10-Jun-00 } & 0 & $\begin{array}{l}9.40 \mathrm{a} \\
(1.32)\end{array}$ & $\begin{array}{l}5.35 \mathrm{~ns} \\
(0.33)\end{array}$ & $\begin{array}{l}0.96 \mathrm{~ns} \\
(0.50)\end{array}$ & $38.49 \mathrm{c}(1.84)$ \\
\hline & 57 & $\begin{array}{l}8.57 \mathrm{ab} \\
(0.71)\end{array}$ & $\begin{array}{l}5.68 \mathrm{~ns} \\
(0.94)\end{array}$ & $\begin{array}{l}0.91 \mathrm{~ns} \\
(0.40)\end{array}$ & $41.06 b(1.43)$ \\
\hline & 170 & $\begin{array}{l}7.84 b \\
(0.52)\end{array}$ & $\begin{array}{l}5.78 \mathrm{~ns} \\
(0.53)\end{array}$ & $\begin{array}{l}1.05 \mathrm{~ns} \\
(0.10)\end{array}$ & 46.36a (2.01) \\
\hline
\end{tabular}


Table 5. Continued

\begin{tabular}{|c|c|c|c|c|c|}
\hline Date & $\begin{array}{c}\text { Treatment } \\
\qquad \begin{array}{c}(\mathrm{kg} \mathrm{N} \\
\left.\mathrm{ha}^{-1}\right)\end{array}\end{array}$ & $\begin{array}{c}\text { Malic } \\
\left(\mathrm{g} \mathrm{kg}^{-1}\right)\end{array}$ & $\begin{array}{c}\text { Citric } \\
\left(\mathrm{g} \mathrm{kg}^{-1}\right)\end{array}$ & $\begin{array}{l}\text { Ascorbic } \\
\left(\mathrm{g} \mathrm{kg}^{-1}\right)\end{array}$ & $\begin{array}{l}\text { Firmness }^{d} \\
\text { (Newtons) }\end{array}$ \\
\hline & 340 & $\begin{array}{l}7.83 \mathrm{~b} \\
(0.72)\end{array}$ & $\begin{array}{l}6.32 \mathrm{~ns} \\
(0.55)\end{array}$ & $\begin{array}{l}1.07 \mathrm{~ns} \\
(0.18)\end{array}$ & 46.91a (1.24) \\
\hline \multirow[t]{4}{*}{ 13-Jun-00 } & 0 & $\begin{array}{l}10.51 \mathrm{a} \\
(1.07)\end{array}$ & $\begin{array}{l}4.69 \mathrm{~ns} \\
(0.80)\end{array}$ & $\begin{array}{l}0.89 \mathrm{~ns} \\
(0.22)\end{array}$ & $41.48 b(0.78)$ \\
\hline & 57 & $\begin{array}{l}9.41 \mathrm{a} \\
(1.41)\end{array}$ & $\begin{array}{l}4.81 \mathrm{~ns} \\
(0.75)\end{array}$ & $\begin{array}{l}0.99 \mathrm{~ns} \\
(0.09)\end{array}$ & $42.85 \mathrm{ab}(0.80)$ \\
\hline & 170 & $\begin{array}{l}9.38 \mathrm{a} \\
(1.05)\end{array}$ & $\begin{array}{l}4.88 \mathrm{~ns} \\
(0.59)\end{array}$ & $\begin{array}{l}1.03 \mathrm{~ns} \\
(0.23)\end{array}$ & 43.09ab (1.06) \\
\hline & 340 & $\begin{array}{l}8.14 b \\
(1.43)\end{array}$ & $\begin{array}{l}4.89 \mathrm{~ns} \\
(0.49)\end{array}$ & $\begin{array}{l}1.04 \mathrm{~ns} \\
(0.22)\end{array}$ & $43.74 a(1.12)$ \\
\hline
\end{tabular}

${ }^{a}$ Means within the columns followed by the same letter are not significantly different at $\mathrm{P}<0.05$ using Fisher's LSD multiple range test.

${ }^{b}$ Mean values are followed by standard deviation in parentheses.

${ }^{c}$ ns: not significant difference.

${ }^{d}$ Kilogram $*$ force $(\mathrm{kgf}) \times 9.807=$ Newton $(\mathrm{N})$

sludges. Although good-quality biosolids (class A) were used in this study, soil EC levels increased to a high of $3.5 \mathrm{dS} \cdot \mathrm{m}^{-1}$ at the high rate of biosolids application for all soil depths after 7 years. The increased salinity levels may eventually be detrimental to apricot production, especially with subsequent applications of biosolids. Maas and Grattan (1999) rank apricot as a salt-sensitive crop with a threshold for yield decline due to soil salinity as low as $1.6 \mathrm{dS} \cdot \mathrm{m}^{-1}$ in a saturated paste extract (ECe).

Overall, both total $\mathrm{N}$ and $\mathrm{C}$ concentrations were significantly greater in the 0 - to $15-\mathrm{cm}$ soil depth with increasing application rates of biosolids. This observation indicates a positive impact on improving soil fertility and soil quality with 7 years of application of good-quality biosolids. Physical properties such as bulk density, water-holding capacity and infiltration rates were not measured in this study, but increased soil carbon can lead to improvements in these soil properties (Bradford and Peterson 2000).

The apparent lack of a significant response in fruit yield to biosolid applications, particularly when no synthetic fertilizers were applied to any of the treatments, indicates that the nutritional status of the soil in our apricot orchard was adequate to sustain apricot yields during the test period. Similarly, other apricot studies did not detect any significant effects on fruit size or weight with applications of additional inorganic fertilizers (Lurie et al. 1996; Nijjar, Deol, and Bajwa 1970; Stockwin 1996). Although fertilizer requirements for apricot production are low and oftentimes nonexistent on productive soils (Ledbetter, personal communication), decreases in fruit 


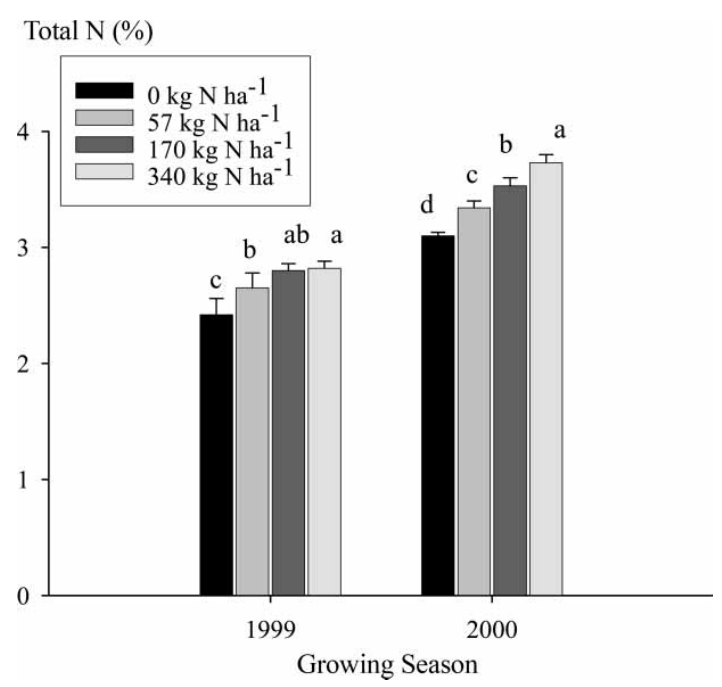

Figure 2. Total $\mathrm{N}$ concentration in apricot leaf tissue (+SD) collected from trees receiving various biosolids application rates in the 1999 and 2000 growing seasons.

yield and quality would eventually be expected in the control plots where no biosolids, or additional fertilizer, were applied as soil nutrient reservoirs became more depleted over time.

Our yield observations in response to biosolid application indicate that increases in fruit yields are not likely to occur; however, some positive effects related to fruit quality, for example, increased macro- and micronutrient concentrations in the fruit and increased firmness can occur. Firmer yellow fruit are generally preferred for canning (French, Kader, and Labavitch 1989). The improved flesh firmness in response to our biosolid applications contrasted with other reports for the Patterson variety of apricots (French, Kader, and Labavitch 1989; Southwick, Yeager, and Weis 1997). The improved firmness may have resulted from higher $\mathrm{Ca}$ concentration observed in the fruit harvested from our high biosolid treatment. Cooper and Bangerth (1976) and Wills, Tirmazi, and Scott (1977) reported that increased $\mathrm{Ca}$ concentrations in other fruits leads to an increase in firmness may even delay fruit ripening. Bangerth (1979) and Marschner (1995) also described in detail the function of $\mathrm{Ca}$ in cell-wall stabilization.

With regard to quality parameters related to apricot taste, biosolid application did not appear to significantly affect sugars or free acidity, but its application did decrease malic acid and slightly increase citric acid content. The application of excessive $\mathrm{N}$ can promote excessive vegetative growth, and the resulting shading can lead to poor fruit color and reduced sugar accumulation (Crisosto et al. 1997; Lurie et al. 1996; Maas and Grattan 1999; Nijjar, Deol, and Bajwa 1970). Although data were not collected on annual pruning weights, visually it appeared that more foliage was removed annually from the 
trees that received high rates of applied biosolids. Similarly, Radi et al. (2003) evaluated different levels of NPK fertilizers on the quality of apricot fruit and found that the mode of $\mathrm{N}$ was most influential on fruit quality. Fruits picked from the 170 and $340 \mathrm{~kg} \mathrm{~N} \cdot \mathrm{ha}^{-1}$ biosolid application treatments reached maturity later (as indicated by more green/yellow fruit at the beginning of harvest) than did fruits from the control and $57 \mathrm{~kg} \mathrm{~N} \cdot \mathrm{ha}^{-1}$ biosolid applications. Delayed fruit maturity has been observed in other stone fruits where high levels of $\mathrm{N}$ accumulated in the soil after 5 years of biosolid applications (Crisosto et al. 1997; Danne et al. 1995; Stockwin 1996). A delay in fruit maturation with biosolid application might be of benefit for small growers, who, with a staggered ripening of fruits, could have fruit available for sale beyond the normal apricot season.

\section{CONCLUSIONS}

Results from this study show that we can safely apply (and dispose of) goodquality biosolids for at least 7 years without negatively affecting apricot fruit production and quality on productive agricultural soils. Moreover, stone fruit trees may be ideal recipients for biosolid applications because of the large capacity for elemental storage in tree trunks, branches, and leaves, should concentrations of certain elements be of concern in some shipments of biosolids. The observed increased fruit firmness and delayed fruit maturity resulting from 7 years of biosolid applications may be advantageous for California apricot growers who export and transport fruit over long distances, as well as for fresh market growers who wish to stagger the harvest of yellow fruit available throughout the growing season. Although we safely increased total $\mathrm{C}$ and $\mathrm{N}$ of the soil with long-term application of biosolids, caution is expressed about the eventual effect of increased soil EC and its eventual detrimental effect on fruit production.

\section{ACKNOWLEDGMENTS}

We acknowledge the financial support from Agriculture Research Initiative, California State University, Fresno (CSUF), and USDA-ARS-WMR. We thank Sanliang Gu at Viticulture and Enology Department CSUF, for his useful comments, and Irvin Arroyo and Tom Pflaum at USDA-ARS-WMR for their analytical assistance.

\section{REFERENCES}

Agricultural Crop and Livestock Report. Fresno Dept. of Agriculture: Fresno, Calif. Available at www.fresno.ca.gor/4010/agwelmcm.htm (accessed on 9 January 2002). 
Allen, R.G., Pereira, L.S., Raes, D., and Smith, M. (1998) Crop evaporation guidelines for computing crop water requirements. In FAO Irrigation and Drainage Paper No. 56; Food, Agriculture Organization of the United Nations: Rome, Italy.

Bangerth, F. (1979) Calcium-related physiological disorders of plants. Annual Review of Plant Phytopathology, 17: 97-122.

Bradford, J.M. and Peterson, G.A. (2000) Conservation tillage. In Handbook of Soil Science; Summer, M.E. (ed.); CRC Press: Boca Raton, Fl. 247-270.

Brown, S.L., Chaney, R.L., Angle, J.S., and Ryan, J.A. (1998) The phytoavailability of cadmium to lettuce in long-term biosolids-amended soils. Journal of Environmental Quality, 7: 1071-1078.

Bryan, H.H. and Lance, C.J. (1991) Compost trials on vegetables and tropical crops. Biocycle, 27: 36-37.

Chaney, R.L. (1994) Trace metal movement: Soil-plant systems and bioavailability of biosolids-applied metals. In Sewage Sludge: Land Utilization and the Environment; Clapp, C.E., Larson, W.E., and Dowdy, R.H. (eds.); ASA, CSSA, SSSA: Madison, Wisc., 27-32.

Chaney, R.L., Hundemann, P.T., Palmer, W.T., Small, R.J., White, M.C., and Decker, A.M. (1978) Plant accumulation of heavy metals and phytotoxicity resulting from utilization of sewage sludge and sludge composts on cropland. In Proceedings of the National Conference Composting Municipal Residues and Sludges; Information Transfer, Inc.: Rockville, MD, 86-97.

Chang, A.C., Hyun, H., and Page, A.L. (1997) Cadmium uptake for swiss chard grown on composted sewage sludge treated field plots: plateau or time bomb? Journal of Environmental Quality, 26: 11-19.

Chang, A.C. and Page, A.L. (2000) Trace elements slowly accumulating, depleting in soils. California Agriculture, (Mar-Apr): 49-55.

Cooper, T. and Bangerth, F. (1976) The effect of Ca and $\mathrm{Mg}$ treatment on the physiology, chemical composition and bitter-pit development of "Cox Orange" apples. Science Horticulture, 5: 49-57.

Crisosto, C.H., Johnson, R.S., Dejong, T., and Day, K.R. (1997) Orchard factors affecting post harvest stone fruit quality. HortScience, 32: 820-823.

Danne, K.M., Johnson, R.S., Michailides, T.J., Crisoto, C.H., Dlott, J.W., Ramirez, H.T., Yokota, G.T., and Morgan, D.P. (1995) Excess nitrogen raises nectarine susceptibility to disease and insects. California Agriculture, 49: 13-17.

Davis, R.D. and Carlton-Smith, C.H. (1984) An investigation into the phytotoxicity of zinc, copper, and nickel using sewage sludge of controlled metal content. Environmental Pollution, 8: 163-165.

Doerge, T.A. and Klaas, L.J. (1996) The fruits of their labor nitrogen management in stone fruit and almond production. Proceedings of 4th Annual Fertilizer Research and Education Program Conference; 1996, Sacramento, Calif.

Faust, J.G. and Oberst, R.L. (1996) Economic value of biosolids to farmers. Biocycle, (Jan): 67-69.

French, D.A., Kader, A.A., and Labavitch, J.M. (1989) Softening of canned apricots: A chilation hypothesis. Journal of Food Science, 54: 86-89.

Furr, A.K., Parkinson, T.F., Elfving, D.C., Buche, C.A., Gutenmann, W.H., Doss, S.J., and Lisk, D.J. (1981) Elemental content of vegetables and apple trees grown on syracuse sludge amended soils. Journal of Agricultural and Food Chemistry, 29: 156-160.

Ledbetter, C.A., Gomez, E., Burgos, Z., and Peterson, J. (1996) Evaluation of fruit quality of apricot cultivars and selection. Journal of Tree Fruit Production, 1: 73-86.

Leuzzi, U. and Licandro, J. (1997) Ion chromatography as a rapid method to distinguish orange juices from second pressure concentrates. Journal of Food Science, 4: 313-322. 
Lurie, S., Zilkah, S., David, J., Lapsker, Z., and Arie, R.B. (1996) Quality of Flamekist nectarine fruits from an orchard irrigated with reclaimed sewage water. Journal of Horticultural Science, 71: 313-319.

Maas, E.V. and Grattan, S.R. (1999) Crop yields as affected by salinity. In Agricultural Drainage, Monograph 38; Skaggs, R.W. and van Schilfgaarde, J. (eds.); ASA, CSSA, SSSA: Madison, Wisc., 55-108.

Marschner, H. (1995) Mineral Nutrition of Higher Plants, 2nd Ed.; Academic Press: San Diego, Calif.

Maynard, A.A. (1995) Cumulative effect of annual additions of MSW compost on the yield of field-grown tomatoes. Compost Science Utilization, 3: 47-54.

National Research Council (1996). Use of Reclaimed Water and Sludge in Food Crop Production; National Academy Press: Washington, D.C.

Nijjar, G.S., Deol, S.S., and Bajwa, M.S. (1970) Effect of nitrogen, phosphorous, and potassium on vigor, cropping, and quality of new castle apricot (Prunus armeniaca Linn.). Journal of Research, 9: 261-263.

Oberle, S.L. and Keeney, D.R. (1994) Interactions of sewage sludge with soil-crop-water systems. In Sewage Sludge: Land Utilization and the Environment; Clapp, C.E., Larson, W.E., and Dowdy, R.H. (eds.); ASA, CSSA, SSSA: Madison, Wisc., 17-20.

Ozores-Hampton, M., Schaffer, B., Bryan, H.H., and Hanlon, E.A. (1994) Nutrient concentrations, growth, and yield of tomato and squash in municipal solid-wasteamended soil. HortScience, 29: 785-788.

Page, A.Z., Chang, A.C., and Bingham, F.T. (1979) Trace metal phytotoxicity and absorption by crop plants grown in sewage sludge amended soils. In International Conference Management and Control of Heavy Metals in the Environmental Land; ECP Consultants: Edinburgh, Scotland, 525-528.

Parr, J.F. and Hormick, S.B. (1992) Utilization of municipal wastes. In Soil Microbial Ecology: Applications in Agricultural and Environmental Management; Metting, F.B. (ed.); Marcel Dekker: New York, 545-559.

Perez Espinoza, A., Moreno-Caselles, J., Moral, R., Perez Murcia, M.D., and Gomez, J. (1999) Effect of sewage sludge and cobalt treatments on tomato fruit yield, weight, and quality. Journal of Plant Nutrition, 22: 379-385.

Pinamonti, F., Stringari, G., Gasperi, F., and Zorzi, G. (1997) Heavy metal levels in apple orchards after the application of two composts. Communications in Soil Science and Plant Analysis, 28: 1403-1419.

Radi, M., Mahrouz, M., Jaouad, A., and Amiot, M.J. (2003) Influence of mineral fertilization (NPK) on the quality of apricot fruit (cv. canino): The effect of the mode of nitrogen supply. Agronomie, 23: 737-745.

Soltanpour, P.N., Johnson, G.W., Workman, S.M., Jones, J.B., and Miller, R.O. (1996) Inductively coupled plasma emission spectrometry and inductively coupled plasma mass spectrometry. In Methods of Soil Analysis, Part 3: Chemical Methods, Book Series No. 5, 3rd edn.; Sparks, D.L. (ed.); ASA, CSSA, SSSA: Madison, Wisc, 91-139.

Southwick, J.M., Yeager, J.T., and Weis, K.S. (1997) Use of gibberellins on "Patterson" apricot (Prunus armeniaca) to reduce hand thinning and improve fruit size and firmness: Effects over three seasons. Journal of Horticultural Science, 72: 645-652.

Stockwin, W. (1996) Boost stone fruit quality. Fruit Grower, (June): 13-16.

USEPA (1993) Standards for the use or Disposal of Sewage Sludge, 40CFR Part 503 final rule.. Federal Register, 58: 9248-9415.

Wills, R.B.H., Tirmazi, S.I.H., and Scott, K.J. (1977) Use of calcium to delay ripening of tomatoes. HortScience, 12: 551-552. 